\title{
Effect of Colchicine-Resistant Familial Mediterranean Fever on Growth Parameters
}

\author{
Kolşisine Dirençli Ailesel Akdeniz Ateşinin Büyüme Parametlerine Etkisi
}

\author{
Betül SÖZERİ, Ebru YILMAZ, Sevgi MİR, Afig BERDELİ \\ Departments of Pediatrics, Medical Faculty of Ege University, İzmir, Turkey
}

Objectives: This study aims to evaluate the growth and development in patients with Familial Mediterranean fever (FMF) resistant to colchicine treatment.

Patients and methods: Eighty-seven patients (45 females, 42 males; mean age $9.6 \pm 3.8$ years; range 2 to 17 years) diagnosed with FMF according to Tel Hashomer criteria in the Pediatric Nephrology Department of Ege University Faculty of Medicine were included in the study. All patients had leukocytosis and elevated C-reactive protein, fibrinojen levels, erythrocyte sedimentation rate and serum amyloid $A$ levels during attacks. The patients were divided into two groups according to colchicine treatment response. Twenty-seven patients ( 13 girls, 14 boys; mean age; $9.9 \pm 3.2$ years) having frequent attacks ( $>1$ attact $/ 3$ month) despite receiving 2 $\mathrm{mg} /$ day colchicine treatment were defined as colchicine-resistant. Sixty patients were defined as colchicine treatment responders. Anthropometric evaluations of the patients were performed at diagnosis and at the end of the follow-up. The height and weight $Z$ scores of patients were used as growth parameters.

Results: No statistically significant difference in mutation frequency was found between the groups. There were no significant differences between both groups in the weight and height $Z$ scores calculated from the anthropometric parameters detected at the diagnosis. In the evaluation performed at the end of the follow-up, we found that the height and weight score for age and the body mass index $Z$ score were significantly decreased in the colchicine resistance group $(p=0.008, p=0.013, p=0.027)$.

Conclusion: Effective suppression of inflammatory response in patients with FMF provides a positive impact on growth. While colchicine is known as the most effective drug in the treatment of FMF, it is known that there are also patients who fail to respond adequately. The patients with colchicine-resistant FMF should be identified in the early period of the disease and treatment should be arranged accordingly. The detection of growth retardation was found to be important in detecting resistance to colchicine in patients with FMF.

Key words: Childhood; colchicine treatment resistance; familial mediterranean fever; growth parameters.
Amaç: $\mathrm{Bu}$ çalışmada Kolşisin tedavisine dirençli ailesel Akdeniz ateşi (AAA) hastalarında büyüme ve gelişme değerlendirildi.

Hastalar ve yöntemler: Ege Üniversitesi Tıp Fakültesi Çocuk Nefrolojisi Kliniği'nde Tel Hashomer kriterlerine göre AAA tanısı konulan toplam 87 hasta $(45 \mathrm{kız}, 42$ erkek; ort. yaş 9.6 \pm 3.8 ; dağılım 2-17 yıl) çalışmaya alındı. Atak sırasında hastaların tümünde lökositoz, C-reaktif protein ve fibrinojen seviyesi yüksekliği, artmış eritrosit sedimantasyon hızı ve serum amiloid A seviyesi yüksekliği vardı. Hastalar kolşisin tedavi yanıtlarına göre iki gruba ayrıldı. Günde $2 \mathrm{mg}$ kolşisin almasına rağmen sık şekilde atak ( $>1$ atak/3 ay) geçiren 27 hasta (13 kız, 14 erkek; ort. yaş $9.9 \pm 3.2$ yıl) kolşisine dirençli şeklinde tanımlandı. Altmış hasta kolşisin tedavisine yanıtlı olarak değerlendirildi. Tanı sırasında ve izlem sonunda hastaların antropometrik değerlendirmeleri yapıldı. Büyüme parametresi olarak hastaların boy ve ağırlık Z skorları kullanıldı.

Bulgular: Gruplar arasında mutasyon sıklığı açısından istatistiksel olarak anlamlı fark bulunmadı. Iki grup arasında tanı sırasında tespit edilen antropometrik değerlerle hesaplanan kilo ve boy $Z$ skorları arasında anlamlı farklılık yoktu. Hastaların izlem sonunda yapılan değerlendirmesinde yaşa göre ağırlık ve yaşa göre boy skorunun ve vücut kütle indeksi $Z$ skorunun kolşisine dirençli grupta anlamlı olarak azaldığı görüldü $(p=0.008, p=0.013$, $\mathrm{p}=0.027$ ).

Sonuç: Ailesel Akdeniz ateşi hastalarında inflamatuvar yanıtın etkin bir şekilde baskılanması büyüme üzerine olumlu bir etki sağlar. Kolşisin AAA hastalığının tedavisinde bilinen en etkin ilaç olmakla birlikte yeterli yanıt alınmayan hastaların olduğu da bilinmektedir. Kolşisin tedavisine dirençli AAA hastalarının erken dönemde tanınması ve tedavisinin uygun şekilde düzenlenmesi gerekmektedir. Ailesel Akdeniz ateşi hastalarında büyüme geriliği saptanması kolşisin direncinin belirlenmesinde önemlidir.

Anahtar sözcükler: Çocukluk dönemi; kolşisin direnci; ailesel akdeniz ateşi; büyüme parametreleri.

\footnotetext{
Received: January 4, 2010 Accepted: April 3, 2010

Correspondence: Betül Sözeri, M.D. Ege Üniversitesi Tıp Fakültesi Çocuk Sağlığı ve Hastalıkları Anabilim Dalı, 35100 Bornova, İzmir, Turkey.

Tel: +90 232 - 3901050 e-mail: betulsozeri@yahoo.com
} 
Familial Mediterranean fever (FMF) is an autosomalrecessive disease caused by a mutation in the Mediterranean fever (MEFV) gene and is characterized by recurrent episodes of fever and sterile peritonitis, arthritis, and/or pleuritis lasting 1 to 4 days. ${ }^{[1,2]}$

Based on MEFV mutation carrier frequency and penetrance studies, it is estimated that around 100.000 individuals from the population-at-risk experience FMF attacks. ${ }^{[3]}$ Currently accepted risk factors for more severe disease and development of amyloidosis are homozygosity to the M694V mutation and to the complex allele V726A-E148Q of MEFV, and male gender. ${ }^{[4-6]}$

Colchicine is the mainstay of FMF treatment because it reduces attack frequency and duration in most patients. ${ }^{[7]}$ In children, the evidence for the effectiveness of colchicine comes from open-label studies. ${ }^{[8,9]}$ Long-term application of colchicine led to complete remission in approximately two thirds and partial remission in approximately one third of patients with FMF. Almost $5 \%$ of patients did not respond to this treatment. ${ }^{[9,10]}$ The dose of colchicine used varied between 1 to $2 \mathrm{mg} /$ day. Prior studies reported that $0.5 \mathrm{mg} /$ day of colchicine in children $<5$ years of age, $1 \mathrm{mg} /$ day for children between five and 10 years of age, and $1.5 \mathrm{mg} /$ day for children $>10$ years of age was successful in the majority of children. ${ }^{[1,12]}$ Failure to respond to $2 \mathrm{mg}$ /day usually predicts a failure of higher doses which also increases the risk of drug toxicity. ${ }^{[10,13]}$

Substantial subclinical inflammation occurs widely and over prolonged periods in patients with $\mathrm{FMF}^{\left[{ }^{[14]}\right.}$ and young patients with chronic inflammatory disease are predisposed to associated growth retardation. Serum amyloid A (SAA) is sensitive for detecting inflammation in such patients. ${ }^{[15]}$ Colchicine therapy prevents recurrent attacks and subclinical inflammation. It also improves growth parameters in FMF patients. Previous studies have shown that colchicine therapy improved growth parameters in children. ${ }^{[16-19]}$ On the other hand, the effect of colchicine treatment resistance on growth and development has not been analyzed.

The aim of the present study was to investigate the effect of colchicine treatment resistance on growth parameters of patients with FMF.

\section{PATIENTS AND METHODS}

Eighty-seven FMF patients (45 girls, 42 boys; mean age $9.6 \pm 3.8$ years; range 2 to 17 years) enrolled in the Medical School of the Ege University Pediatric Nephrology Department, Turkey were included in the study which was approved by the local ethical committee. All patients fulfilled the Tel Hashomer criteria for FMF. ${ }^{[20]}$ Resistance to colchicine therapy was defined as suffering from an attack at any typical site more than once in three months while adhering to a colchicine regimen of $2 \mathrm{mg} /$ day. ${ }^{[21]}$

Thirty-four patients presented with two major criteria while 53 patients presented with one major plus two minor criteria. The patients were divided into two groups according to colchicine treatment response. Twenty-seven (31\%) patients were evaluated as colchicine-resistant while $60(69 \%)$ patients were evaluated as colchicine-responsive who were selected by being gender and age matched with cases of the colchicine-resistant group.

All medical records were reviewed with emphasis on duration of colchicine use, dose of colchicine, presenting symptoms, physical exam findings, laboratory data and outcome. The laboratory tests included complete blood count (CBC), C-reactive protein (CRP), fibrinogen and SAA.

All subjects' weights and heights were measured, and the weight and height standard deviation (SD) scores and body mass index (BMI) were calculated. Body mass index was determined by dividing weight into kilograms by the square of the patients' height in meters. Demographic features, weight, height and BMI scores were recorded and compared for each group before and after colchicine treatment. Patients were considered malnourished when BMI was below the fifth percentile for chronological age, and height/age, weight/age, weight/height, and height/age were below $-2 \mathrm{Z}$-scores for chronological age.

\section{Mediterranean fever gene analysis}

Using blood samples from all patients in both groups, the MEVF gene mutation analysis was performed on $10 ; 5,3,2$ exons of the gene by direct DNA sequence analysis after PCR. The mutation analysis findings were correlated with the clinical data in the colchicineresistant and colchicine-responsive groups.

\section{Statistical analysis}

We compared the categorical data and proportions using the chi-square test or Fisher's exact test as indicated. Means were compared with Student's t-test, and medians were compared with the Mann-Whitney U-test. A value of $\mathrm{p}<0.05$ was considered statistically significant. SPSS software for Windows version 11.0 (SPSS Inc., Chicago, Illinois, USA) was used for statistical analysis. 


\section{RESULTS}

The mean follow up time was $55.2 \pm 26.1$ months (range 24 to 132). The mean age at onset of FMF attacks was $7.1 \pm 3.9$ years. The delay in diagnosis was $2.83 \pm 2.5$ years. Forty-eight patients (55\%) were aware of at least one additional affected family member. Abdominal attacks presented in $83 \%$ of all patients. Articular involvement (arthritis and/or arthralgia) was seen in 45 of 87 patients (51.7\%). Five patients had isolated febrile attacks while six had chest pain. Erysipelas-like erythema was seen in four patients. Abdominal pain along with fever and arthritis was detected more in the colchicine-resistant group than the colchicineresponsive group at the onset of disease $(22.7 \%$ versus $6.7 \%$, respectively; $\mathrm{p}=0.03$ ). Demographic, clinical and laboratory features of all patients are shown in table 1.

Increased CRP, erythrocyte sedimentation rate, fibrinogen and SAA levels were detected in all patients during attack periods. At the end of this study, the frequency of proteinuria (22\%) was similar in both groups while anemia was significantly more prevalent in the colchicine-resistant group (33\% versus $11.7 \%$, $\mathrm{p}=0.016)$. In attack free periods, the mean SAA levels of the colchicine-resistant group was higher than normal values $(<3.3 \mathrm{mg} / \mathrm{dl})$.

Anthropometric evaluations of the patients were made on diagnosis and follow-up. There was no statistically significant difference between both groups for the evaluation of anthropometric parameters upon diagnosis (Table 2). At the end of follow-up, all growth parameters were statistically significantly lower in the colchicine-resistant group than the colchicineresponsive group. The mean of height SDS was lower in the colchicine-resistant group than the colchicineresponsive group $(-0.49 \pm 2.2$ versus $-0.08 \pm 1.28$, respectively, $\mathrm{p}=0.008)$. The mean of weight SDS was lower colchicine-resistant group than the colchicineresponsive group $(-0.63 \pm 2.16$ versus $-0.16 \pm 1.1 .29$, respectively, $\mathrm{p}=0.013)$. The mean BMI SDS was lower in the colchicine-resistant group $(-1.4 \pm 7.57$ versus $-0.3 \pm 2.03$, respectively, $\mathrm{p}=0.027$; Table 2 ).

In our cohort, $44(50.6 \%)$ patients carried one mutation while $43(49.4 \%)$ patients carried two mutations on the MEFV gene. Fifteen patients (55.5\%) had two mutations in the colchicine-resistant group while $28(46.6 \%)$ patients had two mutations in the colchicine-responsive group $(\mathrm{p}=0.29$; Table 3$)$. The distribution of the various common mutations was similar between the colchicine-resistant and colchicine-responsive groups (Table 3). However, the frequency of homozygote M694V mutations was higher in the colchicine-resistant group than the colchicineresponsive group $(n=9,33 \%$ versus $n=11,18.3 \%$, respectively; $\mathrm{p}=0.059)$.

\section{DISCUSSION}

Familial Mediterranean fever is an autosomalrecessive auto-inflammatory disease characterized by recurrent, self-limiting attacks of fever and serositis

\begin{tabular}{|c|c|c|c|c|c|c|c|}
\hline & \multicolumn{3}{|c|}{ Colchicine-resistant } & \multicolumn{3}{|c|}{ Colchicine-responsive } & \multirow[t]{2}{*}{$p$} \\
\hline & $\mathrm{n}$ & $\%$ & Mean \pm SD & $\mathrm{n}$ & $\%$ & Mean \pm SD & \\
\hline \multicolumn{8}{|l|}{ Gender } \\
\hline Female & 13 & & & 32 & & & \\
\hline Male & 14 & & & 28 & & & 0.81 \\
\hline Age at onset of attacks & & & $6.7 \pm 4.2$ & & & $7.2 \pm 3.4$ & 0.61 \\
\hline Age at FMF diagnosis & & & $9.2 \pm 1.9$ & & & $9.9 \pm 3.2$ & 0.41 \\
\hline Delay in diagnosis & & & $1.9 \pm 1.9$ & & & $2.9 \pm 1.9$ & 0.06 \\
\hline Family history & & 57 & & & 52 & & 0.29 \\
\hline \multicolumn{8}{|l|}{ Symptoms } \\
\hline Abdominal attacks & 21 & & & 60 & & & 0.53 \\
\hline Joint attacks & 14 & & & 31 & & & 0.62 \\
\hline Chest attacks & 2 & & & 4 & & & 0.60 \\
\hline Erysipelas-like erythema & - & & & 3 & & & - \\
\hline Isolated febrile attacks & 2 & & & 3 & & & 0.60 \\
\hline Mean SAA levels in attack free period & & & $16.2 \pm 41.5$ & & & $3.8 \pm 1.8$ & 0.04 \\
\hline Hemoglobine levels (g/dl) & & & $12 \pm 1.8$ & & & $12.8 \pm 1.7$ & 0.02 \\
\hline Urine protein levels & & & $12 \pm 3.3$ & & & $4.3 \pm 9.9$ & 0.09 \\
\hline
\end{tabular}


Table 2. Evaluation of the anthropometric parameters at the time of diagnosis and at the end of treatment

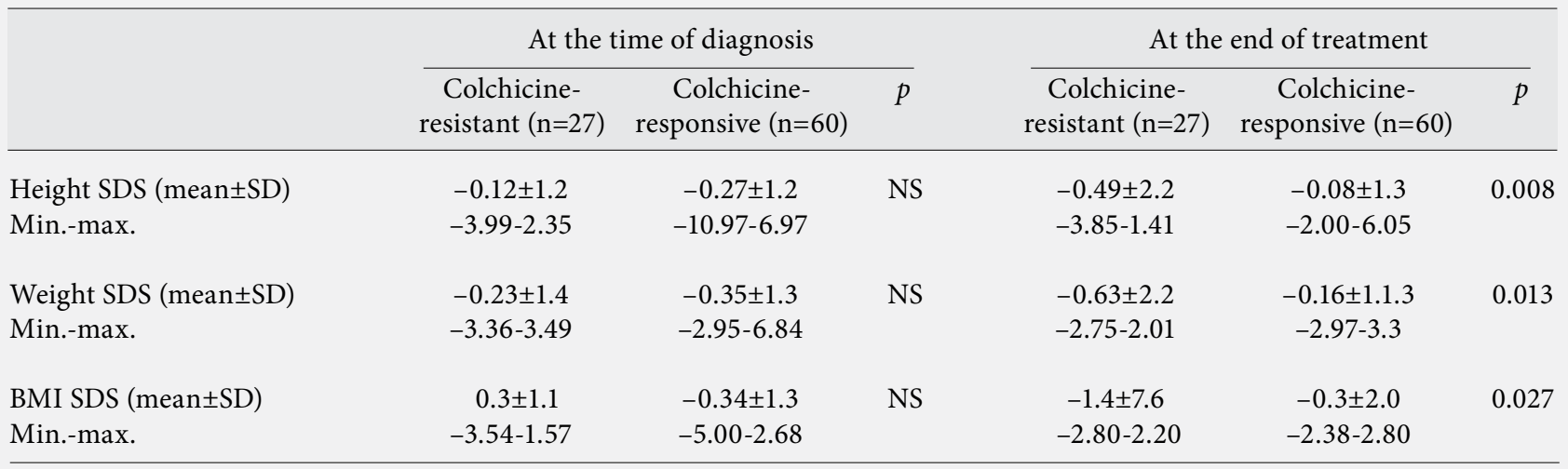

SDS: Standard deviation score; SD: Standard deviation; Min: Minimum; Max: Maximum; NS: Not significant.

including arthritis or erysipelas-like erythema in some individuals. ${ }^{[1,20,22]}$ Colchicine is a very effective drug in treating FMF and it prevents febrile attacks and amyloidosis in both children and adults. ${ }^{[7,9]}$ However, approximately $5-10 \%$ of patients are colchicineresistant. ${ }^{[21]}$

We compared 27 colchicine-resistant patients with 60 colchicine-responsive patients. Our cohort showed that abdominal pain together with fever and arthritis presented mostly in the colchicine-resistant group $(\mathrm{p}=0.03)$. In these patients, abdominal attacks were more often febrile, longer and more severe than in colchicineresponsive patients. This dissimilarity might be associated with decreased treatment efficacy.

Previous studies showed that many chronic, childhood inflammatory diseases are associated with growth retardation coupled with elevated levels of inflammatory cytokines such as interleukin-6 (IL-6), tumor necrosis factor-alpha (TNF- $\alpha$ ) and interleukin- $1 \mathrm{~b}$ (IL-1b). ${ }^{[23,24]}$ Pro-inflammatory cytokines may modulate growth patterns in children with inflammatory diseases through both systemic and local effects of

\begin{tabular}{|c|c|c|}
\hline & $\begin{array}{l}\text { Colchicine- } \\
\text { resistant }(\mathrm{n}=27)\end{array}$ & $\begin{array}{l}\text { Colchicine- } \\
\text { responsive }(n=60)\end{array}$ \\
\hline \multicolumn{3}{|l|}{ Genes } \\
\hline M694V & 16 & 37 \\
\hline E148Q & 4 & 11 \\
\hline M680I & 2 & 8 \\
\hline V726A & 3 & 7 \\
\hline M694I & 1 & 2 \\
\hline \multicolumn{3}{|l|}{ Affected alleles } \\
\hline Homozygotes & 15 & 28 \\
\hline Heterozygotes & 12 & 32 \\
\hline
\end{tabular}

the GH/IGF-1 axes. ${ }^{[23]}$ Elevated levels of circulating IL-6 have been observed in children suffering from inflammatory disease such as juvenile idiopathic arthritis. ${ }^{[25]}$ These patients show reduced circulating IGF-1 levels with unchanged GH levels. ${ }^{[2]}$ The proinflammatory cytokine IL- 6 which caused systemic effects on growth have been examined using the NSE/ hIL- 6 transgenic murine model which overexpresses IL-6. Elevated circulating IL-6 and growth retardation are observed in these mice. ${ }^{[27]}$ Colchicine treatment resistance in patients with FMF is associated with clinical and subclinical inflammation. Serum amyloid A is sensitive for detecting inflammation in such patients. ${ }^{[15]}$ Previous studies showed that effective use of colchicines correlated with normal growth in children with FMF. ${ }^{[9,17,19,28]}$ Zung et al. ${ }^{[18]}$ found that colchicine therapy had a positive effect on both height and weight parameters in children with FMF. Also, Türkmen et al. ${ }^{[16]}$ found that BMI increased during colchicine therapy in their patients. In this context, this is the first study reflecting the influence of colchicine treatment resistance on growth and development in children. We showed that growth parameters (height, weight, and BMI) were significantly lower in the colchicineresistant group than the colchicine-responsive group $(\mathrm{p}=0.008, \mathrm{p}=0.013, \mathrm{p}=0.027$, respectively; Table 2$)$. We also determined that mean SAA levels were higher in the colchicine-resistant group than in the colchicineresponsive group in both the attack period and attackfree period. We believe that the sustained inflammation due to inadequate colchicine efficacy may explain growth impairment in these patients.

Özen et al. ${ }^{[29]}$ showed that the presence of MEFV mutations are predisposed to certain inflammatory diseases. Grimaldi et al. ${ }^{[30]}$ showed that the M694V allele was related to developing acute myocardial infarction. The 
M694V allele is also related to severe phenotypes including amyloidosis. ${ }^{[3-33]}$ The frequency of homozygotes with two M694V mutations was higher in the colchicine-resistant group (37\% versus $18.3 \%$ ), albeit insignificantly. It was suggested that M694V homozygote mutation may have a tendency for inadequacy of colchicine therapy. Lidar et al. ${ }^{[21]}$ showed the allelic homogeneity in colchicine responders and non-responders. We also observed that the distribution MEFV mutations was similar among the groups (Table 3). These results suggest that abnormality in colchicine therapy is distinct from the genetic defect of FMF.

In conclusion, we have demonstrated that colchicine unresponsiveness does not reduce frequency and severity of attacks. Also, colchicine-resistance causes growth impairment because of persistent clinical and subclinical inflammation. Even though colchicine is an effective drug in FMF treatment, FMF patients with colchicine resistance must be recognized in the early period of disease and treatment arranged accordingly.

\section{Declaration of conflicting interests}

The authors declared no conflicts of interest with respect to the authorship and/or publication of this article.

\section{Funding}

The authors received no financial support for the research and/or authorship of this article.

\section{REFERENCES}

1. Sohar E, Gafni J, Pras M, Heller H. Familial Mediterranean fever. A survey of 470 cases and review of the literature. Am J Med 1967;43:227-53.

2. French FMF Consortium. A candidate gene for familial Mediterranean fever. Nat Genet 1997;17:25-31.

3. Gershoni-Baruch R, Shinawi M, Leah K, Badarnah K, Brik R. Familial Mediterranean fever: prevalence, penetrance and genetic drift. Eur J Hum Genet 2001;9:634-7.

4. Cazeneuve C, Sarkisian T, Pêcheux C, Dervichian M, Nédelec B, Reinert P, et al. MEFV-Gene analysis in armenian patients with Familial Mediterranean fever: diagnostic value and unfavorable renal prognosis of the M694V homozygous genotype-genetic and therapeutic implications. Am J Hum Genet 1999;65:88-97.

5. Gershoni-Baruch R, Brik R, Shinawi M, Livneh A. The differential contribution of MEFV mutant alleles to the clinical profile of familial Mediterranean fever. Eur J Hum Genet 2002;10:145-9.

6. Saatçi U, Ozen S, Ozdemir S, Bakkaloglu A, Besbas $\mathrm{N}$, Topaloglu R, et al. Familial Mediterranean fever in children: report of a large series and discussion of the risk and prognostic factors of amyloidosis. Eur J Pediatr 1997;156:619-23.
7. Goldfinger SE. Colchicine for familial Mediterranean fever. N Engl J Med 1972;287:1302.

8. Lehman TJ, Peters RS, Hanson V, Schwabe A. Long-term colchicine therapy of familial Mediterranean fever. J Pediatr 1978;93:876-8.

9. Zemer D, Livneh A, Danon YL, Pras M, Sohar E. Longterm colchicine treatment in children with familial Mediterranean fever. Arthritis Rheum 1991;34:973-7.

10. Kallinich T, Haffner D, Niehues T, Huss K, Lainka E, Neudorf U, et al. Colchicine use in children and adolescents with familial Mediterranean fever: literature review and consensus statement. Pediatrics 2007;119:e474-83.

11. Majeed HA, Carroll JE, Khuffash FA, Hijazi Z. Longterm colchicine prophylaxis in children with familial Mediterranean fever (recurrent hereditary polyserositis). J Pediatr 1990;116:997-9.

12. Majeed HA, Rawashdeh M, el-Shanti H, Qubain H, Khuri-Bulos N, Shahin HM. Familial Mediterranean fever in children: the expanded clinical profile. QJM 1999; 92:309-18.

13. Livneh A, Langevitz P, Zemer D, Padeh S, Migdal A, Sohar E, et al. The changing face of familial Mediterranean fever. Semin Arthritis Rheum 1996;26:612-27.

14. Lachmann HJ, Sengül B, Yavuzşen TU, Booth DR, Booth SE, Bybee A, et al. Clinical and subclinical inflammation in patients with familial Mediterranean fever and in heterozygous carriers of MEFV mutations. Rheumatology (Oxford) 2006;45:746-50.

15. Duzova A, Bakkaloglu A, Besbas N, Topaloglu R, Ozen S, Ozaltin F, et al. Role of A-SAA in monitoring subclinical inflammation and in colchicine dosage in familial Mediterranean fever. Clin Exp Rheumatol 2003;21:509-14.

16. Türkmen M, Soylu OB, Kasap B, Güneş S, Tüfekçi O, Soylu A, et al. Growth in familial mediterranean fever: effect of attack rate, genotype and colchicine treatment. J Pediatr Endocrinol Metab 2008;21:789-92.

17. Ozçakar ZB, Kadioğlu G, Siklar Z, Kavaz A, Nur Aksanal F, Berberoğlu M, et al. The effect of colchicine on physical growth in children with familial mediterranean fever. Eur J Pediatr 2010;169:825-8.

18. Zung A, Barash G, Zadik Z, Barash J. Familial Mediterranean fever and growth: effect of disease severity and colchicine treatment. J Pediatr Endocrinol 2006;19:155-60.

19. Savgan-Gürol E, Kasapçopur O, Hatemi S, Ercan O, Caliskan S, Sever L, et al. Growth and IGF-1 levels of children with familial Mediterranean fever on colchicine treatment. Clin Exp Rheumatol 2001;19(5 Suppl 24):S72-5.

20. Livneh A, Langevitz P, Zemer D, Zaks N, Kees S, Lidar T, et al. Criteria for the diagnosis of familial Mediterranean fever. Arthritis Rheum 1997;40:1879-85.

21. Lidar M, Scherrmann JM, Shinar Y, Chetrit A, Niel E, Gershoni-Baruch $\mathrm{R}$, et al. Colchicine nonresponsiveness in familial Mediterranean fever: clinical, genetic, pharmacokinetic, and socioeconomic characterization. Semin Arthritis Rheum 2004;33:273-82. 
22. Ben-Chetrit E, Levy M. Familial Mediterranean fever. Lancet 1998;351:659-64.

23. MacRae VE, Wong SC, Farquharson C, Ahmed SF. Cytokine actions in growth disorders associated with pediatric chronic inflammatory diseases (review). Int J Mol Med 2006;18:1011-8.

24. Pass C, MacRae VE, Ahmed SF, Farquharson C. Inflammatory cytokines and the GH/IGF-I axis: novel actions on bone growth. Cell Biochem Funct 2009; 27:119-27.

25. Ou LS, See LC, Wu CJ, Kao CC, Lin YL, Huang JL. Association between serum inflammatory cytokines and disease activity in juvenile idiopathic arthritis. Clin Rheumatol 2002;21:52-6.

26. De Benedetti F, Meazza C, Oliveri M, Pignatti P, Vivarelli M, Alonzi T, et al. Effect of IL- 6 on IGF binding protein-3: a study in IL-6 transgenic mice and in patients with systemic juvenile idiopathic arthritis. Endocrinology 2001;142:4818-26.

27. De Benedetti F, Alonzi T, Moretta A, Lazzaro D, Costa P, Poli V, et al. Interleukin 6 causes growth impairment in transgenic mice through a decrease in insulin-like growth factor-I. A model for stunted growth in children with chronic inflammation. J Clin Invest 1997;99:643-50.

28. Ben-Chetrit E, Levy M. Colchicine prophylaxis in familial
Mediterranean fever: reappraisal after 15 years. Semin Arthritis Rheum 1991;20:241-6.

29. Ozen S, Bakkaloglu A, Yilmaz E, Duzova A, Balci B, Topaloglu R, et al. Mutations in the gene for familial Mediterranean fever: do they predispose to inflammation? J Rheumatol 2003;30:2014-8.

30. Grimaldi MP, Candore G, Vasto S, Caruso M, Caimi G, Hoffmann E, et al. Role of the pyrin M694V (A2080G) allele in acute myocardial infarction and longevity: a study in the Sicilian population. J Leukoc Biol 2006;79:611-5.

31. Shohat M, Magal N, Shohat T, Chen X, Dagan T, Mimouni A, et al. Phenotype-genotype correlation in familial Mediterranean fever: evidence for an association between Met694Val and amyloidosis. Eur J Hum Genet 1999;7:287-92.

32. Cazeneuve C, Sarkisian T, Pêcheux C, Dervichian M, Nédelec B, Reinert P, et al. MEFV-Gene analysis in armenian patients with Familial Mediterranean fever: diagnostic value and unfavorable renal prognosis of the M694V homozygous genotype-genetic and therapeutic implications. Am J Hum Genet 1999;65:88-97.

33. Shinar Y, Livneh A, Langevitz P, Zaks N, Aksentijevich I, Koziol DE, et al. Genotype-phenotype assessment of common genotypes among patients with familial Mediterranean fever. J Rheumatol 2000;27:1703-7. 